\section{Comprehensive Primary Health Care in South America: contexts, achievements and policy implications}

\author{
Atención primaria integral en salud en Sudamérica: \\ contexto, logros e implicaciones políticas
}

\section{Abstract}

This article summarizes an extensive review of South American experiences with primary health care since the Declaration of Alma-Ata. It aims to address the following specific questions: What are the enabling and constraining historical and structural conditions for primary health care policies and practices? How has health care reform supported or undermined primary health care? What evidence exists on the effectiveness of primary health care? What strategies are common to best practices? What evidence exists on the roles of citizen participation and intersectoral action? And finally, what are the policy lessons to be learned from these experiences? Narrative synthesis was used to identify and examine patterns in the data consistent with these questions. Conditions that were found to promote successful implementation of primary health care are outlined, together with features of effective primary health care systems that help create more equitable health services and health outcomes.

Primary Health Care; Health Policy; Comprehensive Health Care
Naydú Acosta Ramírez 1

Jennifer Pollard Ruiz 2

Román Vega Romero ${ }^{3}$

Ronald Labonté 4

\section{Introduction}

Diverse interpretations of primary health care have existed since the first international declaration underlining its importance held in Alma-Ata in 1978. The Alma-Ata Declaration on Primary Health Care emphasized that systems should: reflect local needs; integrate social, biomedical and public health activities, including the provision of safe water, food security, local endemic disease control and access to essential drugs; encourage health-related actions across other sectors; work to foster strong community participation. For a number of reasons beyond the scope of this article, other variations on this concept of primary health care quickly arose with emphasis on more selective and basic care approaches 1,2 . Basic care refers to the gate-keeper model that stresses the importance of general practice or family medicine providers as the point of entry into the health system. Selective primary health care focuses on " a limited number of high-impact services to address some of the most prevalent health challenges in developing countries" 2 (p. 19).

This article summarizes an extensive review of South American experiences with primary health care since the 1978 Declaration of AlmaAta. It was conducted between 2007 and 2008 as part of the first phase of a four-year international research/capacity building project: Revitalizing Health for All (RHFA). The RHFA project focused on comprehensive primary health care or prima- 
ry health care experiences that incorporated a rights-based approach to health that meant providing health care to individuals and families and offered a range of other services including:, selfhelp and health education group activities; community development and organization; social action via community mobilization, social marketing and campaigning; working across sectors to bring about community-wide improvement in health status; advocacy and coalition-building to promote changes in policies that affect health equity and its social determinants.

\section{Methods}

The first phase of the review comprised of a comprehensive literature search of seven bibliographic databases conducted by the Canadian research hub using the OVID interface: MEDLINE (1966 to present), EMBASE (1980 to present), HealthStar (1966 to 1998), HealthStar (1999 to present), CINHAL (1982 to present), the Cochrane Central Register of Controlled Trials (1st quarter of 2007) and Socio Abstracts. Search keywords were primary care, comprehensive primary care, primary health care, equity, participatory, intersectoral, multisectoral, access, community capacity, social participation, capacity building, community based research, civil society and social determinants. This search identified 2,059 studies, of which 53 were selected for inclusion in this review using the following criteria: definition of comprehensive primary health care included at least one of the characteristics of comprehensiveness i.e., the system goes beyond the provision of simple primary health care services, programs or policies (incorporation of a rights-based approach, community participation, intersectoral collaboration, comprehensiveness, equity orientation, action on the social determinants of health); the study included empirical data from research processes (i.e., did not just provide a simple commentary); the program or study area was located in Latin America and the date of the program or study was post 1978. Although no methodology or design based criteria were used, the review did assess the robustness of the evidence using norms appropriate to the methodology, which differed for qualitative and for quantitative designs. Of the original 53 studies reviewed, 36 were concerning South America.

The second phase focused on reviewing grey literature obtained through searches of the webpages of regional Ministries of Health, a solicitation to Pan American Health Organization (PAHO) officials and contacts in academic research institutions and Ministries of Health.
The PAHO and Biblioteca Virtual de Salud (BVS) (http://regional.bvsalud.org/php/index.php) databases were also consulted. The original databases identified by the Canadian hub were re-searched using the keywords policy, process, political, plan, planning and implementation. These second phase searches yielded an additional 69 pieces of literature, of which 23 met the inclusion criteria. Fifteen of the total of 59 studies on comprehensive primary health care in South America included in the final review presented here were grey literature (Figure 1).

Studies were examined to identify the effect of comprehensive primary health care on access, vulnerability and risk exposure, social participation, intersectoral action and equity in health outcomes. Topical themes were used to review each article. If an article or study did not significantly explore any one of the following it was not included in the review.

1. Key study questions, designs and methods.

2. Program or study's definition of primary health care.

3. Characteristics of the comprehensive primary health care program or policy;

i. Incorporation of a rights-based approach to health;

ii. Citizen participation;

iii. Intersectoral collaboration;

iv. Service comprehensiveness;

v. Equity orientation: effectiveness at reducing health inequities and stimulating action on the social determinants of health.

4. Lessons learned about the implementation of comprehensive primary health care.

5. Lessons learned about comprehensive primary health care research.

Each program or policy was given a rating of 0,1 or 2 depending on the presence of each of the five comprehensive primary health care characteristics stated above, where: $0=$ characteristic not present, $1=$ minimally present or implicit, and $2=$ strongly present or explicit. A random selection of the articles rated was blindly reviewed and rated by researchers at the University of Ottawa and ratings compared with the South American team's assessment. Any differences were discussed to reach a consensus and ensure clarity on the allocation of future ratings. The rating system was judged as being sufficiently rigorous for ongoing assessment purposes. Findings of the reviews were then juxtaposed, integrated and interpreted using narrative synthesis 3 involving a systematic review process that focused on answering specific research questions. The resulting summary of findings was used to inform the conclusions of this study. 


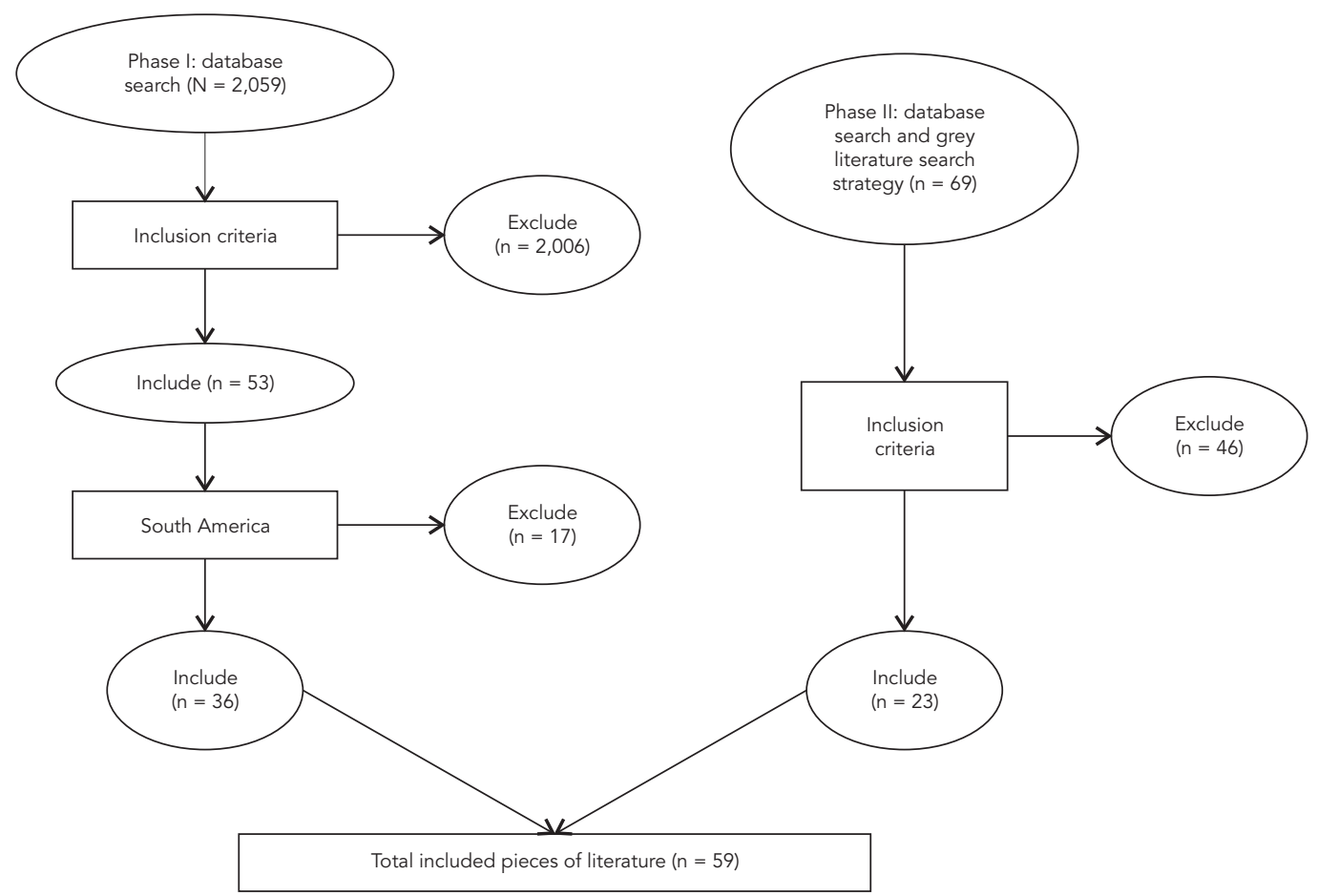

\section{Results}

Features of the studies that met selection criteria

The majority of the studies were carried out in Brazil (25\%), Colombia (14\%), Chile (8\%), Ecuador $(8 \%)$, Argentina (8\%), Bolivia (7\%), Peru (7\%) and Venezuela (7\%). Few studies were carried out in Paraguay (3\%) or Uruguay (2\%), and some were regional analyses including various countries (10\%). The majority of the population served by primary health care programs and policies with some degree of comprehensiveness were marginalized, vulnerable, excluded and/or indigenous. Three general key research questions were explored by the 59 studies selected. The first concerned the health effects of primary health care programs and generated more technical, rigorous or empirical studies $(22 \%)$. The second explored the dynamics of and changes in national primary health care programs over time (10\%). The third question regarded sociopolitical contexts and processes related to primary health care policies and the effects these have on implementation (68\%). Empirical data regarding this question was often descriptive and took a broader, theoretical approach in the form of case studies, syntheses and literature reviews (Table 1).

Highlights from the narrative syntheses are organized into the following three discussions: (1) historical and structural processes that influenced the implementation of comprehensive primary health care in South America; (2) how various types of health care reform supported or undermined comprehensive primary health care; (3) evidence on the effectiveness of comprehensive primary health care in terms of increased equity in access, reduced vulnerability and risk exposure and equitable increases in health outcomes.

The experiences described by the studies fall along an effectiveness spectrum that ranges from complete and ideal implementation of comprehensive primary health care to varying degrees of partial implementation. Some studies concerned the structure of the health system as a whole, while others explored a local program or project 
Study types included in the review.

\begin{tabular}{lcc}
\hline Type of design & Number of studies & $\%$ \\
\hline A. Experimental, quasi-experimental, prospective cohort & 9 & 15 \\
or retrospective cohort & & \\
B. Cross-sectional (with control) & 4 & 5 \\
C. Systematic or narrative synthesis of existing literature & 3 & 2 \\
D. Cross-sectional (without control) & 1 & 68 \\
E. Case study (multiple, comparative or single) & 40 & 3 \\
F. Political position paper & 2 & 100 \\
Total reviewed & 59 & \\
\hline
\end{tabular}

that embodies some of the comprehensive primary health care characteristics of interest.

Historical and structural processes that influenced definitions of primary health care in South America

Public health efforts in the region prior to AlmaAta focused on sanitary measures to control and eradicate infectious disease 4. Subsequently, primary health care was put in place in Latin America with support from the PAHO 5. However, with the exception of a few countries such as Cuba and Costa Rica 6,7, primary health care largely comprised of basic care with a biomedical orientation. For a brief period of time following Alma-Ata, an integrated community oriented approach with support for families and the environment was widely advocated 8 . However, this more comprehensive approach was closely followed by selective primary health care models 9,10 associated with neo-liberal health policies 11 . Structural adjustment policies associated with neo-liberal reforms led to mandatory cuts in public spending, government downsizing, increased reliance on the market and political, administrative and fiscal decentralization 12,13. The result of this process on health policy was a push to privatize services and the adoption an increasingly market orientated approach with minimum, cost-effective interventions targeted at specific groups 14 . These policies led to a general erosion of support for a more comprehensive primary health care model 11 .

Structural social inequality is common to almost all of the countries in the region 15,16,17,18. By the 1980s and 1990s, this had resulted in the formation of segmented health systems in the majority of South American countries which favored the inclusion of urban workers and ex- cluded poor and rural populations ${ }^{19}$. At the same time, the challenges facing these health systems increased due in part to the continuing influence of the epidemiological transition (during which rates of chronic disease began to outstrip rates of infectious disease) and the social organization of responses to the determinants of these chronic conditions 2 .

This review found that $46 \%$ of the studies did not include an explicit definition of primary health care. For those that included a definition, the Declaration of Alma-Ata was the most frequently cited $(\sim 33 \%$ of the studies). However, the employment of this definition varied according to the particular aspects health system reforms and socioeconomic and political circumstances in each country. Some primary health care systems were defined as liberal and neo-liberal models, such as those implemented under Pinochet in Chile in the 1980s and under the Ley $n^{o} .100$ in Colombia in 1993 20,21,22. Other selective primary health care models emerged because of the formation of specific programs or projects such as the Comités Locales de Administración de Salud in Peru 23 and cost-effective nutrition programs in Argentina 24. Other elements identified as important to the shaping of primary health care definitions in South America during this period included model family and community medicine programs or policies $25,26,27$ with an emphasis on the intercultural capacity of primary health care 15 .

Progressive health system reforms informed only $17 \%$ of the definitions of primary health care. Progressive health system reforms across South America show a common pattern in terms of comprehensiveness and universality in health systems and primary health care program design and implementation. The reforms move away from the commercialization and privatization 
of health systems and advocate a stronger role for the state and increased involvement of social movements and community organizations in health services and program decision-making $28,29,30,31,32,33$. Such reforms generally occurred in conjunction with democratization processes embedded within wider economic, social and legal or constitutional changes that framed health as a fundamental human right and developed as part of public policies that emphasized social equity and embraced participative democracy. The biopsychosocial and intercultural health models underlying such reforms also implied a stronger role for the family, community, inter-sectoral service provision and policies and social participation. The empowerment ethos described in many of these reforms valued the family, locally autonomous communities and social organizations for their contributions to self-care, planning, administration, monitoring and evaluation of health system activities, and creating greater political accountability and transparency.

Although they represented the minority of the approaches to comprehensive primary health care described in the literature, progressive health system reforms were of particular inter- est to this study as they tended to fulfill more of the comprehensive primary health care selection criteria and because they were oriented towards achieving health as a right through the creation of equitable access to health services and action on the social determinants of health (Figure 2). These approaches frequently cited Alma-Ata's emphasis on community and family and generated services organized on a territorial basis where the population was assigned to teams of health professionals and health centers. Human resources were geared towards multidisciplinary team practices, horizontal communication between providers, individuals, families and communities 18,22,34 and an intercultural balance between local knowledge and Western medicine $15,16,25$. Health services were seen as political and social processes, highlighting the importance of both community participation and intersectoral service provision 32 . Examples of such reforms were found in the following initiatives: the Salud a su Hogar program (2004) in Bogotá, Colombia 21; the plan Modelo de Salud Familiar Comunitaria Intercultural (2007) in Bolivia 16; the Programa Saúde da Família (PSF) (1994) and the Health Agents Program in Brazil 26,31; the plan AUGE

Figure 2

Current health care reform and comprehensive primary health care in South America.

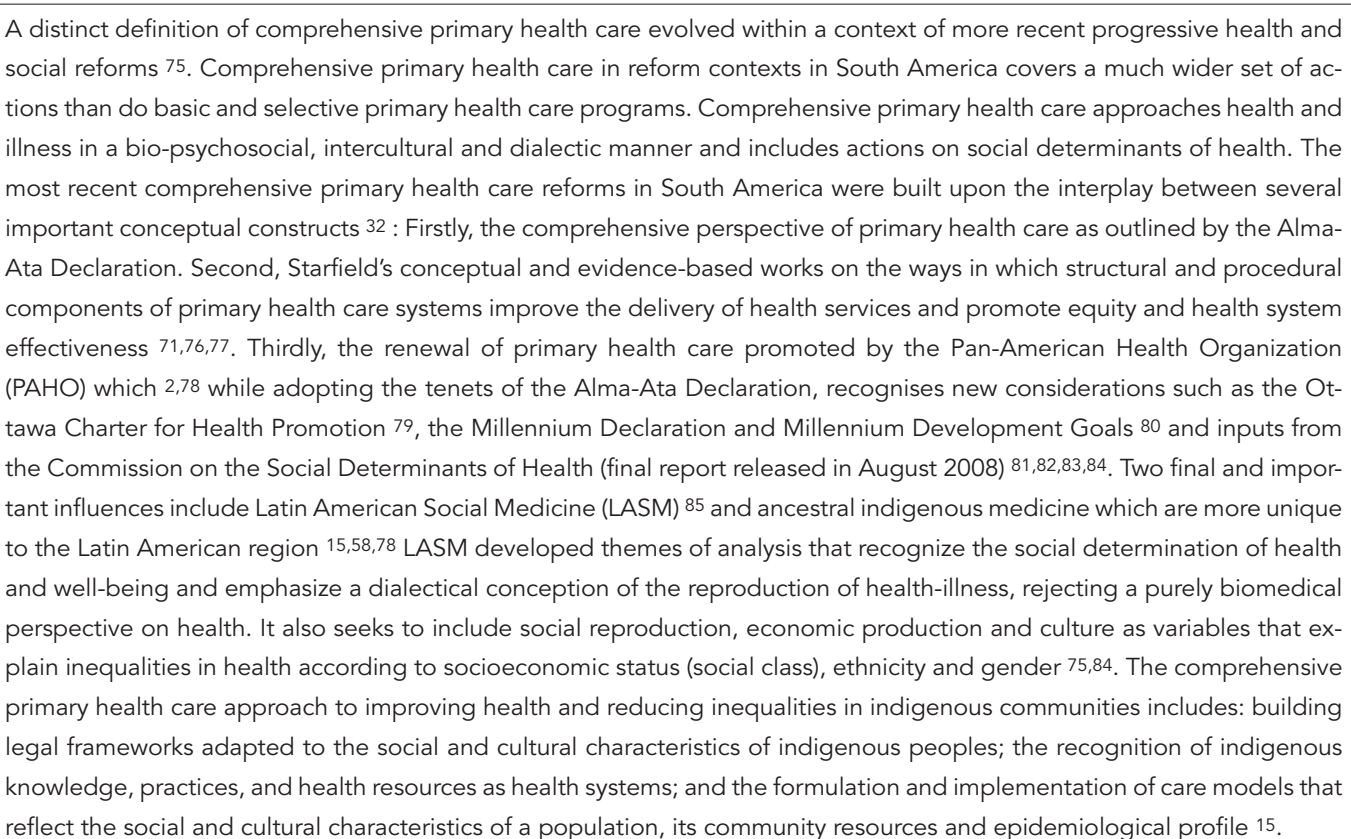


(2004) in Chile 35; the Modelo de Atención Integral en Salud Familiar Comunitaria e Intercultural (2008) in Ecuador 36; the CEMAR program (1989) in Rosario, Argentina 37; the Misión Barrio Adentro program (MBA) (2003) in Venezuela 38.

Thematic analysis of evidence on the effectiveness of comprehensive primary health care programs in South America

In addition to exploring the wider social context behind primary health care development, the purpose of the first phase of the literature review was to derive lessons from past comprehensive primary health care experiences with respect to the five topical themes described above: (1) the incorporation of a rights-based approach to health; (2) citizen participation; (3) intersectoral collaboration; (4) service comprehensiveness, and (5) the equity orientation of health systems: effectiveness at reducing health inequities and stimulating action on the social determinants of health.

The findings for each of these characteristics are discussed below.

\section{- Incorporation of a rights based approach to health}

Rights-based health policies have been developed within the legal and constitutional frameworks of many countries in the region, responding to processes such as social participation, democratization, decentralization, governance and stewardship and a tradition of external and internal sociopolitical and economic influence. In contexts where the rights-based approach was firmly in place and where health care was considered a universal right for all and organized in a unified rather than segmented and fragmented manner, government stewardship of comprehensive primary health care formulation and implementation was considerably stronger. Health was often seen to be a key political issue and an important source of popular struggle 18 . The health issue was a driving force during the development of the Brazilian Constitution of 1988 that established health as a right to be guaranteed by the State. This in turn resulted in the establishment of a unified and universal health system organized under the principles of decentralization and comprehensiveness that currently adopts primary health care as a model of service delivery ${ }^{39}$. Another example of where the rightsbased approach contributed to the effectiveness of comprehensive primary health care was through Articles 83 and 84 of the 1999 Venezuelan Constitution 28 . This legislation declared health a fundamental human right to be guaranteed by the state and created a public health system that provides free health services, prioritizes disease prevention and health promotion and provides for state regulation of both the private and public health sectors 28,34 . Under this constitutional framework, the comprehensive primary health care program, called Barrio Adentro, grew rapidly in neighborhoods that had up until then been excluded from traditional health care coverage. Initially, health needs and demands under this program were identified informally until the creation of Comités de Salud (health committees) 38. Health policies were also created in response to a focus on social justice and social inclusion as the right to health became part of the social exclusion discourse used to demand access to health services 28 .

In cases with a weak rights-based approach, it was more difficult to implement and coordinate primary health care. Fragmented efforts were made through a limited number of initiatives undertaken by progressive local governments such as experiences in Bogotá 22, Colombia and Rosario, Argentina 37.

\section{- Citizen participation}

Rights-based approaches to health system reform were adopted alongside increased social and citizen mobilization and participation. This movement was the impulse for many of the changes made to social and health policy in the 1980 s, 1990 s and 2000s 18,36,39 as community participation in primary health care contributed to enhanced community capacities and resilience. These changes in primary health care were part of a general surge of progressive social, economic and political reforms that provided further leverage for community autonomy, organization and participation, and led to increasing popular demands for government accountability. Brazil and Venezuela provide rich examples of bottom-up approaches with strong community participation and empowerment $18,34,38,40,41$ that had a concrete effect on the formulation, implementation and evaluation of health policies and programs.

In contrast, where community participation occurred within a top-down approach, often as a part of externally mandated funding initiatives, citizen contributions to decision-making were less meaningful and programs did not necessarily lead an improvement in the match between needs and services 17,42,43,44. For example, although neoliberal health reforms implemented in Colombia since 1993 viewed participation as instrumental to the goals of health insurance or 
provider organizations and to identifying needs and subsequent marketing of services, participation was neither conceived as a community right nor as a means for decision making 45 .

Improvements in governance, understood as the symmetric and regulated interaction between civil society and government in the process of identifying problems and solutions, is an important factor in the implementation of a more comprehensive primary health care in South America 46. Various examples from South America suggested that good governance requires the democratization of institutional processes and decision-making and the strengthening of citizen and community autonomy 47,48. Decentralization is one of the approaches to ensure improved democratization. The concept of decentralization took on different meanings in different settings. However, when accompanied by a transfer of power and resources to local communities its presence generally favored more comprehensive primary health care throughout the region, thus enabling better needs identification, priority assignment, decision-making and equitable resource distribution 26,49 . In the case of the health agents program in the State of Ceará, Brazil in the 1990s, for example, decentralization served to strengthen community capacity to voice local needs and interests and made primary health care and health services more accessible, equitable and culturally appropriate 41 (Figure 3 ).

However, some models of decentralization, can constrain community involvement in a number of ways. One study found that the Chilean approach, which adopted a vertical model, failed to build local capacity and knowledge. The more horizontal Brazilian approach, while showing better results in strengthening local capacity to identify, plan and implement activities based on local needs, encountered problems in terms of awareness due to the absence of managerial (hierarchical) controls 50 . In Chile it was shown that the mandatory components of prevention and promotion were less integrated into the health system at local level, whereas in Brazil these components were found to be an integral part of the reorientation of the system, informing cultural changes in the health service.

\section{- Intersectoral collaboration}

Intersectoral collaboration involves various sectors (e.g., health, housing, education, environment and agriculture) working together to solve problems and prevent their causes in a way that no one sector can manage alone. Research on intersectoral action in relation to primary health care was found to be almost absent in this re- gion. However, where examples of intersectoral collaboration were documented, it was found to be combined with citizen participation in joint actions as a response to concerns and interests of both government sectors and community groups. Intersectoral action contributed to the creation of horizontal organizational structures related to, management practices and communication. Several studies 51,52,53 concluded that primary health care programs undertaken within an intersectoral approach, such as Municipios Saludables (Healthy Municipalities) and others that included participative approaches to budget design and allocation, were more successful at engaging community in policy formulation and program planning, implementation and evaluation. These types of actions also had a greater capacity to contribute to actions that addressed social determinants of health and it was found that in-depth community participation and enhanced community empowerment ensured that policy changes were sustainable. The effectiveness of intersectoral actions appeared to be dependent on the level of coordination between primary health care and other social policies or equity-based health promotion strategies. For example, in Bogotá, the "healthy habitat" subsidies component of the Salud a Su Hogar primary health care program, implemented between 2004-2007, brought together various institutions to coordinate improvements in housing and sanitary conditions of experienced by most vulnerable families ${ }^{33}$. In 2006, 466 families were covered by this intersectoral program. New forms of intersectoral action which focus on social risk management are currently being developed in Colombia, albeit not through social assistance programs, but through primary health care programs called Red Juntos y Familias and Acción that adopt a selective approach to primary health care with economic transfer schemes to support poor and vulnerable families. Another example in Venezuela found that state support facilitated coordination between the MBA primary health care program and other state social policies and programs directed at eliminating social inequities. This allowed greater state responsiveness to various social movements and their demands for services resulting in the Misión Robinson literacy program and Las Casas de Alimentación nutrition program 34 .

Intersectoral collaborations often started through personal contacts, but were only sustained at an institutional level through formal mechanisms. One municipality in urban Chile showed strong intersectoral collaboration between the environment and education sectors in which formal local government support and 


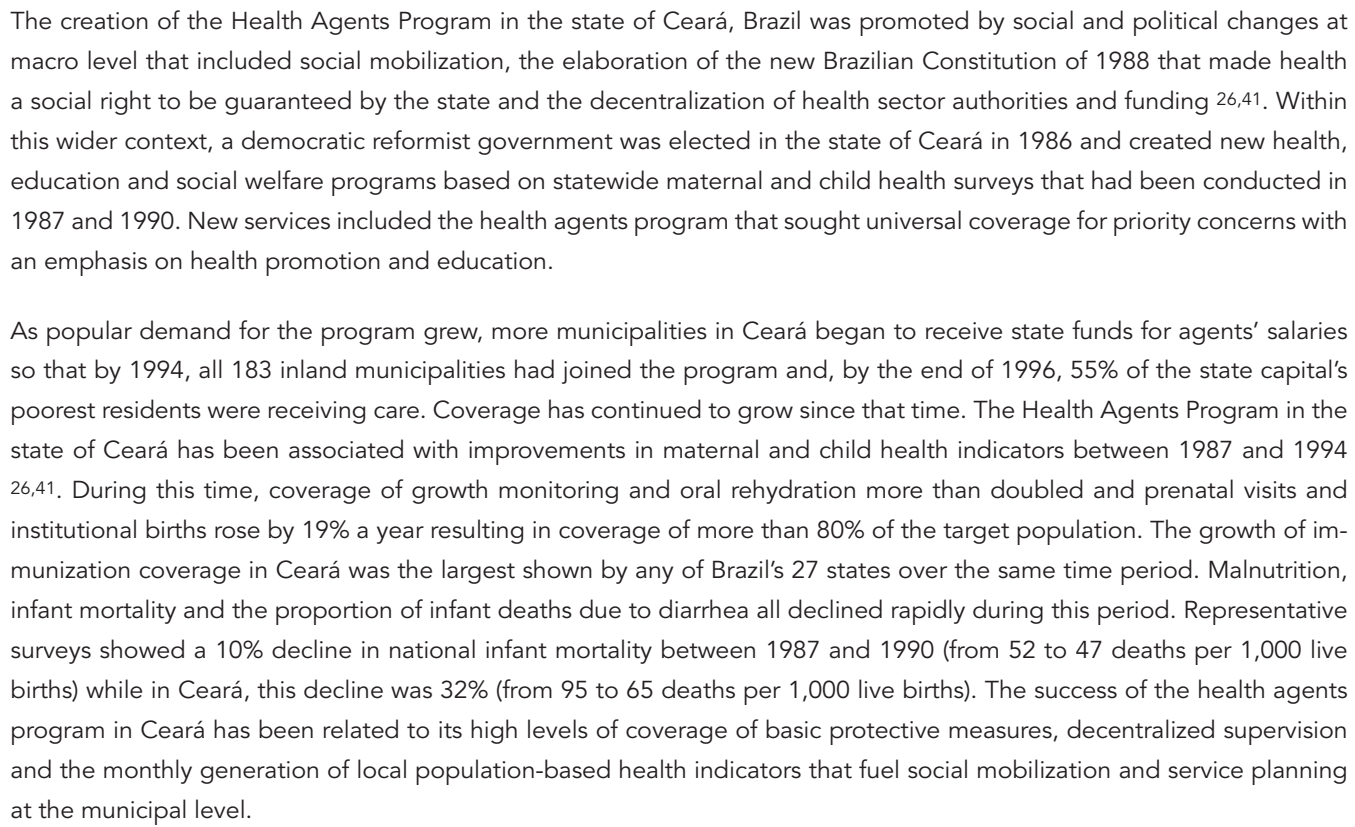

informal personal contacts were important features of interventions 50 . The main obstacle to intersectoral action was the limited capacity of health systems, generally due to the following factors: segmentation and fragmentation of health systems; lack of coordination between health authorities, insurance organizations, levels of care and social services; incapacity of staff to work in an interdisciplinary fashion or across institutional boundaries 35,41. In Argentina, primary health care delivery sites called Centros de Atención Primaria en Salud (CAPS) are well developed and serve as a good point of entry into the health system. But studies undertaken by the country's Ministry of Health found a lack of coordination and collaboration in resolving health needs and argued that their is a need to improve links between the CAPS and external health sector services to be able to address the social determinants of health in a more effective manner. Deficiencies in coordination between different sectors and levels of care were addressed through modifications to the national primary health care policy with the establishment of a specific program, Programa de Fortalecimiento de la Atención Primária a la Salud 54.

\section{- Comprehensiveness of primary health care services}

Comprehensiveness of health care services is defined here as the degree to which health promotion, disease prevention, treatment and rehabilitation services are integrated to respond to individual and collective health needs. A high degree of comprehensiveness occurred where the biomedical, hospital-oriented paradigm had been replaced with a community based approach oriented towards health promotion and disease prevention, guided by more holistic and intercultural notions of health and action on the social determinants of health $21,34,55$. Other factors related to comprehensiveness included the professional development and cultural competency of health staff 56. Primary health care strategies aimed at improving comprehensiveness of services were most effective when the following factors were present: multidisciplinary teams rendered various types of care at the point of service; differing conceptions of health and illness were successfully promoted; coordinated care through all stages of life was provided 57,58. For example, the Makewe-Palale Hospital in Chile, 
a primary health care level site administered by a local Mapuche indigenous association, developed the Intercultural Health Care Model that supports the use of Western medicine to complement the indigenous medical systems already in place. Specific programs at the hospital are based on Mapuche concepts of health and illness and include strengthening cultural identity 59 . Services are tailored to community and culture-specific needs, thereby increasing health service equity by enhancing the acceptability and utilization of services (Figure 4).

An important factor in capacity building for comprehensive service provision has been training and/or orientation for health care staff and management 17,18,34,35,55. Appropriate training and orientation for health care staff and management result in effective gains in capacity to deliver equitable services. In Malvinas, Argentina, the successful implementation of a primary health care intervention was attributed to the provision of primary health care orientation for local health workers who had previously viewed their work as charity 59. The importance of qualified health workers in creating a more equitable distribution of health resources and ensuring that previously excluded groups have access was demonstrated, notably by the Barrio Adentro program in Venezuela 34,59. This program's success relied in large part on the availability of capable health care professionals willing to work and live in poor communities ${ }^{38}$. In another example, a family medicine training program, organized by the Minis- try of Health in Paraguay, played a critical role in strengthening primary health care 60 . A study conducted between 1993 and 2000 in Cajamarca, Peru, similarly showed that the successful implementation of a program designed to increase access to primary health care services, promote community development, improve basic sanitation and guarantee safe water was based upon the development of human resources at local and regional level61.

The principal challenge to achieving comprehensiveness involves the simultaneous integration of diagnosis, treatment and rehabilitation at an individual case level with specific strategies for prevention and promotion at the collective level. Capacity building for multidisciplinary and multi-sector service provision, promotion of community participation, horizontal communication and integrated resource management at the administrative level were also noted to be challenges 17,35,62. D'Ávila Viana et al. 49 found that only 12 (or $20 \%$ ) of the 72 municipalities in the State of São Paulo, Brazil, were achieving comprehensiveness in service provision, citing concentration of technology and mid-level services in few urban areas, while other areas did not have the necessary infrastructure. In Bogotá, Colombia, the dominant biomedical culture posed challenges to developing and sustaining the necessary skills in health workers required to provide comprehensive care within a primary health care framework 22 . Different aspects related to specific characteristics of the health systems and 
the South American context in which they are set have also hindered the achievement of comprehensiveness in primary health care. Despite the Unified National Health System (SUS) in Brazil, that favors the development of comprehensive primary health care, a biomedical and hospital based orientation still persists. Other problems include conflicts between actors due to different political, institutional and ideological interests $40,55,63$, inequality in coverage and quality, and barriers to access to services at all levels 39,49. A common challenge to effective comprehensive primary health care implementation is the existence of segmented and fragmented health systems that involve public sector, social security and private sector provision, as reported in Argentina 54, Chile ${ }^{35}$, Colombia 64, Peru 65 and Ecuador 36 .

\section{- Equity orientation}

Primary health care has played a central role in the construction of universal health systems designed to reduce health inequities 2 . Furthermore, primary health care can also improve health equity by acting on the social determinants of health 66 , including material circumstances, psychosocial factors, behavioral and biological factors, differences in exposure and vulnerability, access to health services and distribution of services 66 . Primary health care is thought to be a mechanism that can transform people's material, psychosocial and biological conditions 28,66,67.

Improved health status of some disadvantaged populations in South America has been associated with increased access to health and social services, attributed in part to primary health care. Various studies reported that primary health care reduces maternal, infant, post-neonatal and under-five mortality and morbidity; reduces morbidity and mortality due to infectious disease; improves perceived access and service utilization; increases immunization rates and access to family planning. For example, a prospective cohort study of a primary health care intervention in rural Bolivia demonstrated that child mortality rates in intervention areas were 4 times lower than in non-intervention areas ${ }^{68}$. In Brazil, a longitudinal ecological study that constructed a series of statistical models using publicly available data for the period 1990 to 2002, showed a $4.6 \%$ decrease in infant mortality rates associated with a $10 \%$ increase in PSF 69 . In Bogota, areas with higher health team coverage rates through the Salud a Su Hogar primary health care program showed lower infant mortality, post-neonatal mortality and pneumonia-related mortality rates in children under five 70 . Venezuela has achieved universal coverage and increased the number of medical visits and new visits. Prior to the Barrio Adentro primary health care program, $88.5 \%$ of service users reported difficulty in accessing services. With the implementation of the program, $98 \%$ of users reported no or very little difficulty in accessing services 34 . Despite political upheaval, recessions, hyperinflation and unemployment in Chile, primary health care policies within the public health system led to sustained reductions in infant mortality rates 20 .

\section{Lessons learned about comprehensive primary health care implementation and research}

The degree of comprehensiveness of the experiences in primary health care in South America was shaped in large part by the prevalent political, socioeconomic and health policy contexts in each country. A high degree of comprehensiveness in primary health care is associated with the following factors: progressive economic and social development models oriented towards more universal health access and social protection, combined with strong public sector presence; decentralized systems with strong social and community participation; systems where the state guarantees the right to health. More basic/ biomedical, selective and targeted approaches to primary health care are characteristic of market-oriented (neoliberal) economic and social development models with strong private sector presence. In these cases, systems are segmented and decentralized, with weak social and community participation and weak health system regulation by the state. In countries where indigenous populations have significant political influence, comprehensive primary health care approaches were used explicitly to develop and implement intercultural health systems. Although studies have not been carried out to demonstrate the advantages of comprehensive primary health care over other primary health care approaches in terms of reduction in health inequities, the evidence reviewed demonstrated that comprehensive primary health care is effective in improving access to health services and other social services, acting on social determinants of health and raising the health status of economically, socially and culturally disadvantaged population groups.

Despite these achievements, the implementation and universalization of comprehensive primary health care have encountered various difficulties:

- One of the main limiting factors is that primary health care is subject to varying interpretations 
and manifestations (i.e., as an intervention strategy, public policy, level of care and/or model of care); and the effects of implementation within segmented and fragmented health systems.

- Problems with primary health care financing include unreliable national sources of funding, lack of sustainability of programs tied to external donors or lenders, and corruption leading to the misuse of funds 17,23,50,68.

- Tension between specialist physicians of differing backgrounds and between medical and non-medical staff, low self-esteem and poor pay among primary health care professionals and difficulty to persuade physicians to work in poor, rural areas serve to constrain primary health care implementation $21,26,34,35$.

- When care workers do not receive adequate training and relationships with communities and health system users are not well nurtured, political, cultural and social support for comprehensive primary health care stagnates. When the focus of care worker training is changed from the hospital and private health care market to the individual and community services, programs become more consistent with the goals of primary health care 6,15,35,39,57.

- Tension exists between different conceptual models underlying the health service (i.e., health as holistic and socially determined services vs. biomedical and market determined services), and between horizontal and hierarchical approaches to service organization. The manner in which these tensions are resolved has implications for medical training, health care worker training, health team structure and communication and capacity to incorporate cultural differences and act on the social determinants of health $18,21,26,28,34,35,38$.

With respect to primary health care research, the following findings were made:

- Multidisciplinary research teams were better able to design studies that fostered knowledge of the multiple dimensions of primary health care actions, such as the dynamics of social participation and actions on health determinants, risk factors and belief and value systems 15,25,52.

- Research on the characterization of health and living conditions, belief and value systems, and disease prevalence and incidence was conducive to services that focused on equity and social determinants of health 15,25,38,54,62. Although research on health equity and disparities outcomes is developing, few rigorous studies of this type were found $34,55,69,70$.

- Primary health care evaluation should include more than traditional biomedical indicators to measure service achievements. Equity changes, service quality, participative mechanisms, in- tersectoral action on the social determinants of health, intercultural perspectives of accessibility and acceptability and patient satisfaction should also be evaluated 15,69,71,72,73 .

- It is necessary to develop evaluation methods that assess primary health care not only as a provider of basic health services, but also as a stimulant of overall human development and provide orientation and guidance for health system planning and implementation at local and national level 56,57,71,72.

An important research technique not found by this review is Participatory Action Research 74 . It has been argued that this technique is a useful tool for developing and implementing needsbased public health strategies because it allows for a more complete understanding of complex problems while creating concerted, participative interventions 25 .

\section{Conclusions and recommendations for a policy agenda}

By elucidating the characteristic patterns of comprehensive primary health care and their relation to primary health care effectiveness, we tentatively conclude that programs that integrate most (or even some) of these characteristics are more successful in achieving health equity outcomes than selective or first level primary care interventions.

In general, primary health care programs that were successful at improving health status and reducing health inequities were found to have the following common features:

- A strong commitment to health as a fundamental human right.

- Service comprehensiveness.

- Creation and support of an appropriately qualified human resources pool for dealing with family and community health.

- Optimization of intercultural care and interdisciplinary teams.

- Equitable geographical allocation of health teams.

- Information systems comprised of individual, family and community health data.

- Needs-based and intercultural practices that focus on marginalized, excluded and vulnerable families, communities and social groups.

- Participatory needs identification and prioritization, and intersectoral local planning of health actions and formulation of public health policy.

- Empowerment of local communities.

- Development in concordance with universal and equitable national health policies or largescale social policies. 
- Mechanisms of accountability in place.

Primary health care programs that were lesssuccessful in implementation were found to have the following common features:

- Difficulties in adopting a paradigm shift from curative, hospital-based care to community and preventative care.

- Segmentation and fragmentation of health system actions.

- Lack of political will with regard to social equity and health as a human right.

- Inadequate coordination between local, national and international interests.

- Inadequate use of local data and lack of appropriate human skills.

- Weak community participation, multidisciplinary and/or intersectoral action.

- Volatile macro-economic and socio-political environment.

These findings, in turn, imply several policy directions for comprehensive primary health care development, suggesting which policies should de pursued and which should de avoided. Comprehensive primary health care reforms to maximize health equity such should also be ac- companied by rigorous implementation studies and outcome evaluations. The existing evidence base on the effectiveness of comprehensive primary health care in South America still tends towards low to middle quality of findings that, while substantial, can be improved.

\section{Study limitations}

Attempts were made to capture all appropriate studies undertaken on primary health care in South America since 1978. In order to control selection bias, studies in multiple languages were included, as was grey literature from local journals, universities, research centers and health ministries. However, it is possible that primary health care programs or experiences may not have been included due to the absence of corresponding published or grey literature. The thematic analysis could have been more effective if an evaluation of the quality of evidence cited had been included. This type of quality evaluation was considered initially but was not pursued due to the large volume of case studies and the line of questioning posed by the global study.

\section{Resumen}

Este artículo resume una extensa revisión de experiencias de atención primaria en salud en Suramérica desarrolladas desde la Declaración de Alma-Ata. Se abordaron preguntas específicas: ¿Cuáles son las restricciones y facilitadores estructurales y del contexto histórico para las políticas y experiencias de atención primaria en salud? ¿Cómo las reformas en salud las han favorecido o limitado? ¿Qué evidencia existe de la efectividad de la atención primaria en salud? ¿Cuáles son las estrategias comunes de las mejores prácticas? ¿Qué evidencia existe del rol de la participación comu- nitaria y la acción intersectorial? Y finalmente, ¿Cuáles son las lecciones políticas aprendidas? Se empleó una síntesis narrativa para identificar y examinar las tendencias en los hallazgos a esas preguntas. Se describen las condiciones encontradas que favorecen el éxito de la implementación de la atención primaria en salud y las características que fueron efectivas para lograr servicios y resultados de salud equitativos.

Atención Primaria de Salud; Política de Salud; Atención Integral de Salud 


\section{Contributors}

N. Acosta Ramírez, J. Pollard Ruiz, R. Vega Romero and R. Labonté contributed to the conceptualization and drafting of the article and participated in the data analysis and interpretation, critical review of the article, and final approval of the version to be submitted for publication.

\section{Acknowledgments}

This work was made possible through funding provided by the Teasdale-Corti Global Health Research Partnership Program, a collaborative health research program developed by the four founding partners of the Canadian Global Health Research Initiative - Canadian Institutes of Health Research, International Development Research Centre, Health Canada and Canadian International Development Agency - with input from the Canadian Health Services Research Foundation. We acknowledge the support given by the facilitators of the project, most notably the University of Ottawa and the University of the Western Cape.

\section{References}

1. Labonté R, Sanders D, Baum F, Schaay N, Packer C, Laplante D, et al. Implementation, effectiveness and political context of comprehensive primary health care: preliminary findings of a global literature review. Aust J Prim Health 2008; 14:58-67.

2. Pan-American Health Organization/World Health Organization. Renewing primary health care in the Americas: a position paper of the Pan-American Health Organization/World Health Organization. Washington DC: Pan-American Health Organization/World Health Organization; 2007.

3. Popay J, Roberts H, Sowden A, Petticrew M, Arai L, Rodgers M, et al. Guidance on the conduct of narrative synthesis in systematic reviews. Final report. Lancaster: ESRC Methods Programme; 2006.

4. Cueto M. Los ciclos de erradicación: la Fundación Rockefeller y la salud pública Latinoamericana, 1918-1940. In: Cueto M, editor. Salud, cultura y sociedad en América Latina. Lima: Instituto de Estudios Peruanos/Organización Panamericana de la Salud; 1996. p. 179-202.

5. Organización Panamericana de la Salud/Organización Mudial de la Salud. Salud para todos en el año 2000: estrategias. Washington DC: Organización Panamericana de la Salud/Organización Mudial de la Salud; 1980.
6. Gilpin M. Update Cuba: on the road to a Family Medicine Nation. J Public Health Policy 1991; 12:83-103.

7. Villegas de Olazábal H. Atención primaria de salud y salud para todos: Costa Rica y Centro América. Escenarios, participación, desafíos siglo XXI. In: Ministerio de Salud Costa Rica/Caja Costarricense de Seguro Social/Organización Panamericana de la Salud/Organización Mudial de la Salud, editors. Atención primaria de salud en Costa Rica: 25años después de Alma-Ata. San José: Organización Panamericana de la Salud/Organización Mudial de la Salud; 2005. p. 21-58.

8. Organización Panamericana de la Salud/Organización Mudial de la Salud. Desarrollo y fortalecimiento de los sistemas locales de salud en la transformación de los sistemas nacionales de salud. Washington DC: Organización Panamericana de la Salud/Organización Mudial de la Salud; 1988. (Documento CD 33/14).

9. Magnussen L, Ehiri J, Jolly P. Comprehensive versus selective primary health care: lessons for global health policy. Health Aff (Millwood) 2004; 23:167-76

10. Cueto M. The origins of primary health care and selective primary health care. Am J Public Health 2004; 94:1864-74. 
11. Solar O, Irwin A. Social determinants, political contexts and civil society action: a historical perspective on the Commission on Social Determinants of Health. Health Promot J Austr 2006; 17:180-5.

12. Laurell AC. La política de salud en el contexto de las políticas sociales. In: Bronfman M, Castro R, editors. Salud, cambio social y política: perspectivas desde América Latina. México DF: Edamox; 1999. p. 239-52.

13. Almeida C. Reforma de sistemas de salud y equidad en América Latina y el Caribe: algunas lecciones de los años 80 y 90. Cad Saúde Pública 2002; 18:905-25.

14. Laurell AC. La lógica de la privatización en salud. In: Eibenschutz C, editor. Política de saúde: o público e o privado. Rio de Janeiro: Editora Fiocruz; 1995. p. 31-48.

15. Pan-American Health Organization. Harmonization of indigenous and conventional health systems in the Americas, strategies for incorporating indigenous perspectives, medicines, and therapies into primary health care. Washington DC: PanAmerican Health Organization; 2002.

16. Ministerio de Salud y Deportes de Bolivia. Modelo de salud familiar comunitaria e intercultural. http://www.sns.gov.bo/viceministerio/deportes/ promocion_salud/salud_comunitaria/index.htm (accessed on 14/Feb/2007).

17. Homedes N. Managing externally financed projects: the Integrated Primary Health Care Project in Bolivia. Health Policy Plan 2001; 16:386-94.

18. Labra ME, Giovanella L. Brazil: building the unified national health system and civil society participation. Geneva: World Health Organization; 2007.

19. Frenk J, Gonzalez-Block MA. Primary care and reform of health systems: a framework for the analysis of Latin American experiences. Health Serv Manag Res 1992; 5:32-43.

20. Jimenez J, Romero MI. Reducing infant mortality in Chile: success in two phases. Health Aff (Millwood) 2007 ; 26:458-65.

21. Vega Romero R, Carrillo Franco J. APS y acceso a universal a los servicios de salud en las condiciones del SGSSS de Colombia. "El caso de Salud a su Hogar” en Bogotá. Rev Gerenc Políticas Salud 2006; 5:38-52.

22. Vega Romero R. Los orígenes y desarrollos de la APS en Colombia. In: Vega Romero R, Acosta Ramírez N, Mosquera Mendez P, Restrepo Vélez O, editors. Atención primaria integral de salud: estrategia para la transformación del sistema de salud y el logro de la equidad en salud. Bogotá: Alcaldía Mayor de Bogotá/Secretaría Distrital de Salud/ Pontificia Universidad Javeriana; 2009. p. 53-82.

23. Iwami M, Petchey R. A CLAS act? Communitybased organizations, health service decentralization and primary care development in Peru. Local Committees for Health Administration. J Public Health Med 2002; 24:246-51.

24. Ortiz-Andrellucchi A, Quintana L, Acar AA, Barros FM, Serra-Majem L. Child subnutrition, health and poverty, integral intervention programme. Nutr Hosp 2006; 21:533-41.
25. Puertas B, Schlesser M. Assessing community health among indigenous populations in Ecuador with a participatory approach: implications for health reform. J Community Health 2001; 26: 133-47.

26. Emond A, Pollock J, Costa N, Maranhão T, Macedo A. The effectiveness of community-based interventions to improve maternal and infant health in the Northeast of Brazil. Rev Panam Salud Pública 2002; 12:101-10.

27. Conill EM. Políticas de atenção primária e reformas sanitárias: discutindo a avaliação a partir da análise do Programa Saúde da Família em Florianópolis, Santa Catarina, Brasil, 1994-2000. Cad Saúde Pública 2002; 18 Suppl:191-202.

28. Muntaner C, Salazar RM, Rueda S, Armada F. Challenging the neoliberal trend, the Venezuelan health care reform alternative. Can J Public Health 2006; 97:I19-23.

29. Alvarado CH, Martínez ME, Vivas-Martínez S, Gutiérrez NJ, Metzger W. Cambio social y política de salud en Venezuela. Medicina Social 2008; 3:113-29.

30. Borgia F. La salud en Uruguay: avances y desafíos por el derecho a la salud a tres años del primer gobierno progresista. Medicina Social 2008; 3:130-47.

31. Cohn A. La reforma sanitaria brasileña: la victoria sobre el modelo neoliberal. Medicina Social 2008; 3:87-99.

32. Laurell AC. Sacando a las reformas progresistas de la sombra. Medicina Social 2008; 3:83-6.

33. Vega Romero R, Acosta Ramírez N, Mosquera Méndez PA, Restrepo Vélez MO. La política de salud en Bogotá, 2004-2008: análisis de la experiencia de atención primaria integral de salud. Medicina Social 2008; 3:148-69.

34. Organización Panamericana de la Salud/Organización Mundial de la Salud. Barrio Adentro: derecho a la salud e inclusión social en Venezuela. Caracas: Organización Panamericana de la Salud/Organización Mundial de la Salud; 2006.

35. Montenegro H, Girard J, Duarte D, Oyarzún R. Análisis de las políticas públicas de atención primaria de salud en Chile. http://pwr-chi.bvsalud. org $/ \mathrm{dol} /$ docsonline/get.php?id=252 (accessed on 24/Feb/2007).

36. Ministerio de Salud Pública del Ecuador. Salud de los pueblos indígenas: acceso y calidad de la atención en salud. Quito: Ministerio de Salud Ecuador; 2008.

37. Rovere M. La salud en el municipio de Rosario: aportes a la construcción de una gobernabilidad democrática. In: Programa de las Naciones Unidas para el Desarrollo; Gobierno de la Municipalidad de Rosario, editors. Experiencia Rosario: políticas para la gobernabilidad. Rosario: Programa de las Naciones Unidas para el Desarrollo/Gobierno de la Municipalidad de Rosario; 2006. p. 107-64.

38. Briggs CL, Mantinni-Briggs C. Misión Barrio Adentro: medicina social, movimientos sociales de los pobres y nuevas coaliciones en Venezuela. Salud Colect 2007; 3:159-76. 
39. Escorel S, Giovanella L, Mendonça MHM, Senna MCM. O Programa de Saúde da Família e a construção de um novo modelo para a atenção básica no Brasil. Rev Panam Salud Pública 2007; 21:164-76.

40. Raupp B. Planejamento participativo em serviços de atenção primária à saúde. Estudo comparativo de duas experiências: Porto Alegre e Montevidéu. Rev APS 2007; 10:169-72.

41. Cufino Svitone E, Garfield R, Vasconcelos MI, Craveiro VA. Primary health care lessons from the Northeast of Brazil: the Agentes de Saude Program. Rev Panam Salud Pública 2000; 7:293-302.

42. Morgan LM. Community participation in health: perpetual allure, persistent challenge. Health Policy Plan 2001; 16:221-30.

43. Biagini G. Sociedad civil y salud en Latinoamérica: aproximaciones al estado del arte de las investigaciones. In: V Conferencia Regional de ISTR, Sociedad Civil, Participación Ciudadana y Desarrollo. http://lasociedadcivil.org/docs/ciberteca/g_bia gini.pdf (accessed on 02/Jun/2011).

44. Zakus JDL. Resource dependency and community participation in primary health care. Soc Sci Med 1998; 46:475-94.

45. Restrepo Vélez MO, Vega Romero R. Participación social y comunitaria en atención primaria de salud - APS. Bogotá: para la muestra un botón. Rev Gerenc Políticas Salud 2009; 8:153-64.

46. Mayntz E. El Estado y la sociedad civil en la gobernanza moderna. Revista del CLAD Reforma y Democracia 2001; (21). http://www.clad.org.ve/ rev21/mayntz.pdf (accessed on 27/Sep/2007).

47. Báscolo E, Yavich N. Condiciones de gobernanza de políticas e intervenciones tendientes a fortalecer la APS en espacios municipales. In: Instituto de la Salud Juan Lazarte, editor. Gobernanza, equidad y atención primaria de la salud. Rosario: Instituto de la Salud. Juan Lazarte; 2006. p. 97-120.

48. Acosta Ramírez N, Vega Romero R. El caso de la implementación de la estrategia de APIS en la localidad de Suba. Rev Gerenc Políticas Salud 2008; 7:125-44.

49. D’Ávila Viana AL, Yazle Rocja JS, Elias PE, Ibañez N, Novaes MHD. Modelos de atenção básica nos grandes municípios paulistas: efetividade, eficácia, sustentabilidade e governabilidade. Ciênc Saúde Coletiva 2006; 11:577-606.

50. Atkinson S, Cohn A, Ducci ME, Gideon J. Implementation of promotion and prevention activities in decentralized health systems: comparative case studies from Chile and Brazil. Health Promot Int 2005; 20:167-75.

51. Mendes R, Falvo F. Motuca healthy municipality project: building together a better future. Promot Educ 2007; 14:81-2.

52. Rice M, Franceschini MC. Lessons learned from the application of a participatory evaluation methodology to healthy municipalities, cities and communities initiatives in selected countries of the Americas. Promot Educ 2007; 14:68-73.
53. Scannavino C, Anastácio R. Promoting health and happiness in the Brazilian Amazon. Promot Educ 2007; 14:85-7.

54. Ministerio de Salud, Presidencia de la Nación. Dossier nacional de atención primaria en salud y la integración con otros niveles de atención, República de Argentina. Intercambio III.2-1-2007. Fortalecimiento de la integración de la atención primaria con otros niveles de atención. http://www. ensp.fiocruz.br/eventos_novo/dados/arq6954.doc (accessed on 07/Feb/2007).

55. Ronzani TM, Stralen CJ. Dificuldades de implantação do Programa de Saúde da Família como estratégia de reforma do sistema de saúde brasileiro. Rev APS 2003; 6:7-22.

56. Macinko J, Almeida C, Klingelhoefer DSP. A rapid assessment methodology for the evaluation of primary care organization and performance in Brazil. Health Policy Plan 2007; 22:167-77.

57. Macinko J, Almeida C, Oliveira DSE, Klingelhoefer DSP. Organization and delivery of primary health care services in Petrópolis, Brazil. Int J Health Plann Manage 2004; 19:303-17.

58. Ibacache Burgos J, Chureo F, McFall S, Quidel Lincoleo J. Promoción de la medicina y terapias indígenas en la atención primaria de salud: el caso de los Mapuche de Makewe-Pelale de Chile. Washington DC: Organización Panamericana de la Salud; 2001. (Serie Salud de los Pueblos Indígenas, 16).

59. Burrone MS, Fernandez AR, Acevedo GE, Lucchese MSM, Lopez de Neira MJ, Dell Inocenti P, et al. Análisis de estrategias de atención primaria de salud en el municipio de Malvinas Argentinas: un abordaje cuanti-cualitativo. Rev Esc Salud Pública 2007; 11:7-22.

60. Ministerio de Salud Pública y Bienestar Social. Dossier nacional de atención primaria en salud y la integración con otros niveles de atención. Asunción: Ministerio de Salud Pública y Bienestar Social; 2007.

61. Altobelli LC, Castillo O, Medina J. Misión de evaluación externa final, proyecto APRISABAC, "Atención Primaria y Saneamiento Básico de Cajamarca" Cajamarca - Perú 1993-2000. Informe final. http:// www.phc-amsterdam.nl/userfiles/file/bijlagen/ aprisabac\%20final\%20resumen.pdf?PHPSESSID $=59063081 \mathrm{af} 2 \mathrm{db} 128 \mathrm{a} 4426768 \mathrm{ca} 00188 \mathrm{e}$ (accessed on $22 / \mathrm{Feb} / 2008$ ).

62. Carrasquilla G. An ecosystem approach to malaria control in an urban setting. Cad Saúde Pública 2001; 17 Suppl:171-9.

63. Béhague DP, Gonçalves H, Dias-da-Costa JS. Making medicine for the poor: primary health care interpretations in Pelotas, Brazil. Health Policy Plan 2002; 17:131-43.

64. Toro DF, Revelo MD, Lozada E, Cuadros OF, Cuadros LM, Diron LN, et al. La estrategia de atención primaria: un horizonte para el logro de comunidades saludables. Cali: Fundación Carvajal/Fundación FES/Fundundación Restrepo Barco/Universidad del Valle/Gobernación del Valle del Cauca; 1996. 
65. Organización Panamericana de la Salud. Promoción de la medicina y terapias indígenas en la atención primaria de salud: el caso de los Quechuas de Perú. Washington DC: Organización Panamericana de la Salud; 2002. (Serie Salud de los Pueblos Indígenas, 18).

66. Organización Mundial de la Salud. Subsanar las desigualdades en una generación: alcanzar la equidad sanitaria actuando sobre los determinantes sociales de la salud. Ginebra: Organización Mundial de la Salud; 2008.

67. Rifkin SB, Walt G. Why health improves: defining the issues concerning "comprehensive primary health care" and "selective primary health care". Soc Sci Med 1986; 23:559-66.

68. Perry HB, Shanklin DS, Schroeder DG. Impact of a community-based comprehensive primary health care program on infant and child mortality in Bolivia. J Health Popul Nutr 2003; 21:383-95.

69. Macinko J, Guanais FC, Marinho de Souza MF. Evaluation of the impact of the Family Health Program on infant mortality in Brazil. J Epidemiol Community Health 2006; 60:13-9.

70. Mosquera Méndez PA, Granados Hidalgo G, Vega Romero R. La estrategia de atención primaria en salud (APS) para Bogotá-Colombia y su relación con la disminución de las inequidades de resultados en salud. Rev Gerenc Políticas Salud 2008; 7:87-109.

71. Starfield B. Atención primaria. Barcelona: Masson; 2001.

72. Harzheim E, Duncan BB, Stein AT, Cunha CRH, Gonçalves MR, Trindade TG, et al. Quality and effectiveness of different approaches to primary care delivery in Brazil. BMC Health Serv Res 2006; 6:156.

73. Labonté R, Sanders D, Baum F, Schaay N, Packer C, Laplante D, et al. Aplicación, efectividad y contexto político de la atención primaria integral de salud: resultados preliminares de una revisión de la literatura mundial. Rev Gerenc Políticas Salud 2009; 8:14-29.

74. Burns D. Evaluation in complex governance arenas: the potential of large system action research. In: Williams B, Imam I, editors. Systems concepts in evaluation: an expert anthology. Fairhaven: American Evaluation Association; 2006. p. 181-96.
75. Laurell AC. What does Latin American social medicine do when it governs? The case of the Mexico City government. Am J Public Health 2003; 93: 2028-31.

76. Macinko J, Starfield B, Shi L. The contribution of primary care systems to health outcomes within OECD countries, 1970-1998. Health Serv Res 2003; 38:819-53.

77. Starfield B, Shi L, Macinko J. Contribution of primary care to health systems and health. Milbank Q 2005; 83:457-502.

78. Organización Panamericana de la Salud. Atención primaria de salud en las Américas: las enseñanzas extraídas a lo largo de 25 años y los restos futuros. Washington DC: Organización Panamericana de la Salud; 2003. (CD44/9 Es).

79. World Health Organization. Ottawa charter for health promotion, 1986. http://www.who.int/hpr/ NPH/docs/ottawa_charter_hp.pdf (accessed on 03/Jun/2011).

80. Pan-American Health Organization. The millenium development goals. http://www.paho.org/ english/mdg/cpo_thematic.asp (accessed on 03/ Jun/2011).

81. Commission on Social Determinants of Health. Action on the social determinants of health: learning from previous experiences. Geneva: World Health Organization; 2005.

82. Commission on Social Determinants of Health. Towards a conceptual framework for analysis and action on the social determinants of health. Geneva: World Health Organization; 2005.

83. Gilson L, Doherty J, Loewenson R, Francis V; Knowledge Network on Health Systems. Final report. Geneva: World Health Organization; 2007.

84. Knowledge Network on Health Systems. Challenging inequity through health systems. Geneva: WHO Commission on the Social Determinants of Health; 2008.

85. Iriart C, Waitzkin H, Breilh J, Estrada A, Merhy EE. Medicina social latinoamericana: aportes y desafíos. Rev Panam Salud Pública 2002; 12:128-36.

Submitted on $26 / \mathrm{Jan} / 2010$

Final version resubmitted on $08 / \mathrm{Jul} / 2010$

Approved on 18/May/2011 